\title{
ECOS EUROPEOS NA FORMACIÓN DO NACIONALISMO GALEGO. AS IRMANDADES DA FALA (1916-1923)
}

Ramón Villares

Universidade de Santiago de Compostela 

Avogado, non -dixo Edith, a irmá de O'Brian, hastra entón calada-. Non, doce amigo. Vosté [Adrián Soutelo] será poeta, loitador. Faría un bó feniano! Ramón Otero Pedrayo, Os camiños da vida, 1928

É idea admitida na literatura especializada que as Irmandades da Fala (IF), fundadas na cidade da Coruña en maio de 1916, son o punto de partida do moderno nacionalismo político da Galicia contemporánea. Vinculadas explicitamente á reivindicación da lingua galega no plano cultural e á procura dunha «autonomía integral» no plano político, a súa evolución ideolóxica e política foise decantando desde presupostos rexionalistas cara ao nacionalismo, definición que as propias IF adoptan na primeira asemblea política, realizada en Lugo en novembro de 1918. As IF foron o principio dun novo movemento político en Galicia que, de forma progresiva, se foi equiparando con iniciativas análogas, aínda que anteriores no tempo, desenvolvidas en Cataluña e Euskadi, que foran unha resposta aos retos provocados pola crise de 1898, ao gran debate sobre o rexeneracionismo en España e, como é natural, ás repercusións que tivo a Gran Guerra europea, a partir de agosto de 1914. As IF galegas participan deste contexto histórico, por máis que a súa aparición fose relativamente serodia, e só se podería considerar circunstancial o feito de que coincidan no tempo cun dos episodios máis sobranceiros daquela altura, como foi o levantamento irlandés (Easter Rising) na Pascua de 1916. A fundación das IF pode entenderse, por tanto, máis como un fenómeno epocal interno que como un acontecemento conectado directamente coa aparición de organizacións europeas de «nacionalidades» ou de «minorías nacionais», antes e despois de 1914 (por exemplo, a Union des Nationalités, 1912). Alén diso, as IF deben entenderse como unha ruptura xeracional, 
na medida en que acceden á vida pública novas capas sociais, mesocráticas e urbanas, que tratan de axustar contas cos seus devanceiros, axuste ben resumido na metáfora de Antón Villar Ponte das «verbas vivas» (por exemplo, nacionalismo) como antídoto fronte ás «verbas mortas» (por exemplo, rexionalismo «sano y bien entendido»), que parecen ecos distantes do darwinismo da fin-de-siècle aplicados, neste caso, á transición do rexionalismo ao nacionalismo cultural e político que as IF protagonizan nos seus primeiros anos de vida.

O obxectivo deste traballo é analizar a aparición e primeiros pasos das IF, entre 1916 e 1923, en canto expresión galega dun proceso que ten explicacións endóxenas, pero que tamén forma parte dunha tendencia moito máis ampla, de dimensión peninsular e mesmo europea, na que se encontran algúns referentes decisivos para entender o xurdimento do nacionalismo galego. $\mathrm{O}$ contexto galego no que aparecen as IF está marcado por varios fitos. En primeiro termo, polas mudanzas estruturais que se producen no campo e no mar, isto é, na modernización da agricultura e na aparición dun auténtica "revolución industrial» nas actividades marítimas, coa expansión da pesca e a creación dun sector manufactureiro liderado pola industria de conservas, e polos efectos de arrastre que estas actividades teñen na construción naval e outras industrias anexas (Carmona e Nadal 2005). En segundo termo, pola forte mobilización social representada polo agrarismo da Acción Gallega de Basilio Álvarez e por un programa de reformismo técnico do mundo rural elaborado nas Asembleas Agrarias de Monforte (1908-1911), que trataba de dar resposta a demandas seculares do campesiñado galego coa eliminación das vellas formas de cesión da terra mediante a redención de foros e, sobre todo, fomentar un amplo proceso de individualismo posesivo mediante o acceso masivo dos campesiños á propiedade plena da terra e a incorporación da pequena explotación campesiña ao mercado (Villares 1982; Cabo 1998). E, en terceiro termo, pola existencia dunha forte corrente migratoria, esencialmente con destino ás repúblicas americanas, que transformou de maneira radical a sociedade rural galega, tanto polo éxodo producido como polos efectos de retorno, mediante remesas «visibles» de capitais e remesas de natureza 
«invisible», de carácter cultural, político e simbólico, que mudaron de vez a sociedade galega do primeiro terzo do século pasado (Núñez Seixas 1998; Vázquez 2015).

Neste marco tiveron, asemade, unha influencia decisiva algúns feitos ou ecos externos que permiten entender tanto a aparición das IF como o proceso previo mediante o que tivo lugar a toma de conciencia, por parte dunha elite cultural e política galega, que leva á fundación deste movemento. A reflexión rexeneracionista sobre os límites do sistema político español e a necesidade da súa reforma alentou alternativas políticas novas, definidas inicialmente como rexionalistas, desde a crise de 1898, que a certa altura alcumou Antón Villar Ponte como «el batacazo del 98». De feito, o rexionalismo catalán aparece como tal en 1901 e algunhas das súas estratexias, como a alianza con diversas forzas políticas (desde os republicanos ata os carlistas), permiten abrir as primeiras fendas no sistema da Restauración a partir das eleccións de 1905 e 1907 (Riquer 2001: 185 e ss.). Este exemplo de «nova política» fóra do turnismo ou alternancia pacífica foi un estímulo para as IF galegas e os seus primeiros pasos organizativos, cando tentaron establecer alianzas concretas co nacionalismo catalán representado por Francesc Cambó. Por outra banda, o conflito bélico desatado en agosto de 1914 tivo unha influencia decisiva nas políticas nacionais europeas, como amosa o exemplo de Irlanda, pero tamén na proliferación de movementos nacionais en moitas pequenas patrias europeas, que tería a súa expresión máis acaída nas propostas do presidente americano Woodrow Wilson de converxencia entre feitos lingüísticos e creación de novos Estados-nación. O que tamén poderiamos chamar «batacazo de 1914» exerceu efectos profundos non só sobre as políticas estatais, senón, alén diso, sobre as posicións ideolóxicas dos grandes partidos tradicionais, que a través da Union sacrée viraron rapidamente cara ao nacionalismo, o que foi «un feito europeo común en 1914»(O’Brien 1999: 10).

A evolución da guerra mundial e a preparación dos tratados de paz levantaron moitas expectativas sobre o nacemento dunha era histórica na que novas nacións substituirían os vellos imperios. Ademais, as políticas nacionais da revolución 
soviética reforzaron a idea de que parecían compatibles a revolución social e a identidade nacional, aparentemente respectada na denominación da URSS como unha unión de repúblicas soviéticas. Todo parecía anunciar, de Irlanda a Mitteleuropa ou das posicións teóricas de Wilson ás de Lenin, que se abría un novo horizonte para a cuestión nacional na inmediata posguerra, o que resultou máis problemático do esperado (Núñez Seixas 2001). Como diría un membro do Grupo Nós, «cand'a loita [guerra mundial] semellaba acabar, aló na lonxana Rusia [...] xurdiu c’unha ameaza, a pantasma da revolución social» (López Alonso-Cuevillas 1920). A euforia de finais de 1918 alentou claramente os dirixentes das IF galegas, que reforzaron a súa definición nacionalista como unha estratexia non só de facer fronte á crise de Estado na España de Afonso XIII, senón tamén de evitar as consecuencias sociais da revolución bolxevique. E, alén diso, este contexto favoreceu as alianzas externas ou, polo menos, os espellos nos que mirarse: Irlanda e Portugal, de forma preferente. Estes dous espellos permiten analizar de maneira comparada os grandes retos das IF galegas: modelo organizativo e tensión entre prioridades estratéxicas (nacionalismo cultural ou nacionalismo político), e, ademais, confrontar os resultados das primeiras Irmandades coa diagnose dun dos seus principais teóricos e dirixentes (Risco 1930) sobre os bloqueos que, a xuízo do escritor ourensán, padecían os dous partidos políticos, o agrario e o nacionalista, cos que Risco soñaba naquela altura.

\section{UN MANIFESTO E UN NOME}

As IF aparecen en maio de 1916 como un movemento especificamente cultural que, no plano político, se define como rexionalista. A organización e a capacidade mobilizadora do rexionalismo galego foran moi notables na última década do século XIX, baixo o liderado de Manuel Murguía e de Alfredo Brañas, que lograron colocar Galicia no contexto da «España regional», nome tamén dunha revista editada en Barcelona que marcou o debate político do rexionalismo peninsular 
ata a crise do 98. No caso de Galicia, organizacións como a Asociación Regionalista Gallega (Santiago) ou a Liga Gallega (A Coruña), así como a promoción de poderosos símbolos ou lieux de mémoire, como o Panteón de Galegos Ilustres, o monumento aos mártires de Carral ou a creación da Academia Galega, son exemplos desta obra rexionalista, que, ademais, contou coa poderosa axuda das colectividades da emigración galega en América (Máiz 1984; Villares 2017). No entanto, a invocación ao rexionalismo por parte das primeiras IF non era unha garantía de continuidade organizativa, porque, a diferenza do acontecido no País Vasco e, nomeadamente, en Cataluña, o rexionalismo galego non foi capaz de mudar cara ao nacionalismo político logo do profundo impacto político que tivo en España a derrota colonial do 98, malia térense ensaiado fórmulas como a de Solidaridad Gallega (1907), claramente influída pola experiencia da Solidaritat Catalana, pero con resultados políticos moito máis fracos (Cabo 2006). A aparición das IF é, por tanto, un proceso algo diferente do que acontecera no conxunto dos rexionalismos peninsulares, tanto por ter lugar de forma serodia como pola ausencia en Galicia de organizacións políticas capaces de liderar procesos de mobilización de carácter rexionalista fronte ao sistema político da España da Restauración, «oligárquico e caciquil», en palabras de Joaquín Costa.

As IF nacen, pois, nun tempo e nun contexto verdadeiramente singulares. Nacen nunha España neutral no conflito bélico europeo, con influencias ideolóxicas e políticas procedentes do rexeneracionismo de Costa e do catolicismo social, pero tamén da experiencia interna da Solidaridad Gallega e das Asembleas Agrarias de Monforte. Da primeira herdan o nome do seu voceiro xornalístico, A Nosa Terra, fundado polos «solidarios» da cidade da Coruña en 1907, e das segundas, un programa de reforma técnica do sector rural galego e a experiencia de varios líderes, entre os que cómpre salientar a figura de Rodrigo Sanz, verdadeiro mentor daquelas asembleas e, no plano político, ben conectado co rexionalismo catalán de Francesc Cambó. A esta tradición rexionalista e «solidaria», agrarista e vagamente federal-republicana, habería que engadir o pulo procedente dun núcleo de galegos residentes en Madrid e, como é natural, a 
forza societaria da emigración americana. A persoa que decantou esta variedade de influencias foi o xornalista Antón Villar Ponte, coa publicación do seu folleto Nacionalismo gallego. Nuestra afirmación regional, difundido en abril de 1916, que está na base da primeira reunión dunha Irmandade da Fala, un mes máis tarde, nos locais da Real Academia Galega, na cidade da Coruña.

No título, nos contidos e mesmo na dedicatoria deste folleto están resumidas as primeiras liñas mestras deste movemento que nace como resultado dunha campaña xornalística anterior e que acabaría por alcanzar o carimbo de ser o punto de arranque das IF. Era un texto que se pode definir como un manifesto político e claramente propagandista, que tivo a virtude de lograr amplas adhesións dentro e fóra de Galicia. A dedicatoria do folleto indica cales eran os referentes de Villar Ponte naquela altura, aqueles que denomina «cinco gallegos ejemplares, siempre despiertos» (Aurelio Ribalta, Rodrigo Sanz, Manuel Lugrís, Antonio Valcarce e Constantino Horta). Neses nomes resúmense algunhas ideas fortes da prehistoria das Irmandades: anticentralismo, federalismo, galeguismo, defensa do idioma e loita pola «emancipación galega» no exterior americano..., pero tamén unha evidente ruptura coa tradición rexionalista, patente na omisión do nome do presidente da Academia Galega, Manuel Murguía, e doutros referentes próximos, como os rexionalistas da Cova Céltica (o poeta Eduardo Pondal, o libreiro Euxenio Carré, o publicista Francisco Tettamancy...).

Este manifesto de Villar Ponte é o resultado dun estado de opinión que se advertía desde había dous anos, tanto en Galicia como en Madrid, sobre os dous problemas que van centrar o ideario das IF: a defensa da lingua galega e o estudo dos problemas económicos de Galicia. O promotor das IF publicara dous anos antes un artigo («El gallego no debe morir», La Voz de Galicia, 9.5.1914) no que sostiña que a lingua propia era sinónimo de «pensar por sí mismos» e un modo de combater o «separatismo» do Estado central, que marxinaba as rexións periféricas. $\mathrm{O}$ contexto político estaba marcado tamén polos debates sobre o rexionalismo político, con feitos como a instauración da Mancomunitat de Catalunya (1913), un debate parlamentario sobre a cooficialidade do catalán (1915) ou, para 
o caso concreto de Galicia, a creación dunha cátedra universitaria de literatura galega (1913), atribuída á Universidade de Madrid e non á Minerva compostelá. Alén destas reivindicacións culturais, foi decisiva a aparición en Madrid da revista Estudios Gallegos como «espoleta do rexurdir do galeguismo en Galicia» (Beramendi 2007: 429). A revista, subtitulada Lenguaje, Finanza y Turismo, publicouse durante os anos 1915-1916, baixo a dirección de Aurelio Ribalta. Publicación de orientación rexeneracionista e de influencias «solidarias», tivo unha ampla nómina de colaboradores, entre os que deben salientarse Amador Montenegro, Eloy Luis André, Lois Porteiro ou Rodrigo Sanz, que é o autor dunha serie de artigos nos que resume o traballo desenvolvido polo movemento «solidario» e polas asembleas agrarias de Monforte. Na realidade, este grupo de galegos asentados en Madrid, con presenza habitual no Ateneo, defende unha reforma en profundidade do agro galego, a mellora das comunicacións e o abandono do proteccionismo arancelario, o que resume en boa medida o futuro programa das IF e, logo, do nacionalismo galego da II República representado polo Partido Galeguista. A toma de conciencia sobre a cultura e a lingua galegas, así como a vontade de superar mediante a acción política a marxinación de Galicia, están, pois, moi presentes nesta campaña que precede a fundación das IF. Con todo, será a cultura e non a política a marca definidora do percurso das IF ata os tempos da II República.

Un manifesto político e un nome pouco convencional. Era previsible que adoptase o nome de Liga, dado que, naquela altura, era moi frecuente escoller unha palabra diferente da de Partido para designar un novo movemento cultural e político: así se denominou no caso catalán (Lliga Regionalista, 1901) e noutras rexións europeas (Ligue Valdôtaine, 1909; Ligue nationale pour la défense de la langue française, da Valonia belga, 1910). Deste modo opinaba tamén un dos primeiros adheridos á proposta de Antón Villar Ponte, o notario monfortino Manuel Banet Fontenla, quen soñaba cunha forte «Liga Rexionalista de Galicia», non centrada exclusivamente na "defensa do idioma». A palabra Liga formaba parte, pois, do léxico político e societario daquela época, xa que tamén así 
se denominaron numerosas organizacións agrarias e grupos de interese corporativo, tanto en España como en toda Europa, desde Irlanda ata Italia ou Alemaña. Liga foi tamén o nome dalgunhas organizacións impulsadas polas colectividades da emigración (a Liga Santaballesa foi a promotora en Galicia da primeira escola de emigrantes «americanos») e semellante nome adoptaron movementos de reivindicación cultural ou lingüística, como a irlandesa Gaelic League e tantos outros exemplos. Mesmo na tradición galega se encontra unha importante Liga Gallega nos tempos do rexionalismo finisecular, e «Liga de Acción Gallega» foi o nome que tomou o movemento agrarista dirixido por Basilio Álvarez desde 1907. Os exemplos poderían multiplicarse. Por que se escolleu o nome de «Irmandades» non está explicado cabalmente en ningures. De acreditar no testemuño de Ramón Villar Ponte, sería unha solución máis comunicativa que conceptual. Dun chamamento a fundar unha «Liga de Amigos del Idioma» (que era a proposta inicial do seu irmán Antón) pasouse a unha «Hirmandade dos Amigos da Fala», logo «Hirmandades da Fala Gallega»e, «pra ficar o nome mais curto», finalmente optouse polo de «Irmandades da Fala» (Villar Ponte e Cabanillas 1977: 20).

No entanto, o nome dado polos fundadores ao movemento que estaba a nacer en maio de 1916 conecta claramente cunha tradición cultural e asociativa moi enraizada na historia de Galicia. Irmandiños ou hermandinos eran os que loitaron nas guerras do mesmo nome, a finais do século XV, logo do soerguemento organizado en varias vilas e cidades galegas contra os señores feudais e as tropas do Reino de Castela. As guerras irmandiñas e algunhas das súas figuras, como o mariscal Pardo de Cela, foron recuperadas e mitificadas pola literatura romántica, especialmente polo historiador Benito Vicetto, autor que, a xuízo de Antón Villar Ponte, era un «Walter Scott galego». No seu romance de tipo cabaleiresco Los hidalgos de Monforte (1851), cuxa trama se desenvolve no tempo das guerras irmandiñas, Vicetto refírese a «los hermanos de Galicia» cun lema que faría fortuna na Galicia contemporánea: Deus fratresque Gallaeciae; isto é, en palabras do propio Vicetto, «Dios y los hermanos de Galicia será la divisa de la 
terrible hermandad», organizada contra a política dos Reis Católicos e da alta nobreza galaica. Un referente medieval foi o punto de partida para a construción da identidade galega por parte dos románticos, como acontecía en moitos lugares de Europa (Thiesse 1999; Villares 2017). Estas resonancias «irmandiñas», expresión dun revival medievalizante herdado do rexionalismo pero adoptado con forza polos nacionalistas das IF, estaban lonxe do concepto político da «fraternidade revolucionaria» de orixe francesa e moito máis próximas a unha visión cristiá, de trazos franciscanos, que tivo no poeta Ramón Cabanillas a súa mellor expresión (Agra e Mariño 2017).

Por outra banda, a escolla do nome parece estar moi influenciada polo aprecio que, naquela altura, se lles tiña á natureza, á vida campestre e mesmo ás árbores. Desde principios do século XX apareceron en diversas cidades e vilas de Galicia manifestacións desta nova visión da natureza, a través das Festas da Árbore, prácticas de excursionismo e organizacións de Amigos de los Árboles como a fundada na cidade da Coruña, en 1911, por José María Hernansáez, da que formaron parte numerosos socios procedentes de familias de profesionais e mercantís da mesocracia coruñesa (Fariñas, Martínez Morás, Salorio Rubine, Rodríguez Pastor, Bescansa, Wonemburger, Barcia... e o propio Antón Villar Ponte). Esta vinculación das Irmandandes co excursionismo non estaba só no nome, senón tamén nas prácticas. Así como os amigos das árbores saían de forma periódica ao campo, tamén os membros das Irmandades da Fala adoptaron desde a súa fundación un modelo de difusión do seu ideario mediante excursións dominicais a diferentes vilas de Galicia. A primeira foi a un lugar ben próximo á cidade da Coruña, «asiñalando como punto de reunión o gran piñal de Elviña, nos arredores da Cruña, piñal que fitado ao lonxe semellaba un gran corazón». Esta excursión reunía en si mesma varias mensaxes: amor pola natureza, lugar coroado por un castro con forma de corazón concibido como creador de afectos e, ademais, presenza do poeta Ramón Cabanillas, considerado xa polos primeiros membros das IF como o vate que «[viña] a remover [...] a [súa] apatía, a esperta[los] do [seu] sono mortal»(Villar e Cabanillas 1977: 20-21). 
Alén desta tradición galega, a aparición das IF está conectada con movementos producidos fóra de Galicia que acabaron, de modo máis ou menos casual, fecundando o proceso galego. Un exemplo evidente era a Irmandade Republicana Irlandesa (Irish Republican Brotherhood), que logrou unha importante mobilización social e cultural na época "prerrevolucionaria», particularmente a través da súa infiltración na Liga Gaélica (Foster 2015: 90; Paseta 1999: 149). Un xuízo algo posterior de Risco, nos primeiros números da revista Nós que se ocupan da cuestión irlandesa, vén a confirmar este paralelismo, cando observa: "A Liga Gaélica formouse en Irlanda moito antes [1893], coa mesma finalidade qu'as nosas Irmandades da Fala» (Nós, 8: 20). A idea de irmandade sería máis forte que a de fraternidade franciscana, pero tamén que a de partido ou movemento político. Porque tiña algo de apostolado social que conectaba cunha concepción católica do mundo e porque a irmandade permitía reforzar a solidariedade dos seus membros a través de lazos afectivos máis fortes que as ideas. A definición ulterior das IF por parte do grupo ourensán Nós, de tradición orientalista e neosófica, insistirá claramente nestes trazos ideolóxicos e organizativos, nos que un certo secretismo e ocultismo serían prácticas habituais, como é patente no diálogo epistolar entre Vicente Risco e Losada Diéguez (Ventura 2010: 110).

\section{PROGRAMA E ORGANIZACIÓN}

A Irmandade da Fala fundada na Coruña tivo réplicas de inmediato noutras cidades e vilas galegas, ata superar o número de vinte núcleos, desde Compostela ata Monforte, Vilalba, Betanzos, Ferrol, Viveiro, A Estrada ou Pontevedra. A maior implantación territorial das IF coincide en gran medida cos núcleos da anterior Solidaridad Gallega, máis fortes nas provincias setentrionais que meridionais de Galicia. A constitución destas Irmandades locais foi resultado de sucesivas campañas de prensa e tamén de xiras ou visitas a cada localidade por 
parte dos irmandiños coruñeses, que, ao modo dunha misión relixiosa, transmitían a boa nova a grupos mesocráticos locais. En realidade, as IF representan de modo cabal a práctica común dos partidos nacionalistas daquela altura en España: ser máis un movemento que un partido, fixar unha militancia laxa entre os seus membros e defender unha dirección colexiada do movemento, o que, no seu conxunto, supuña manter unha actuación descentralizada e un predominio da afiliación indirecta, quer de figuras a título persoal, quer de entidades culturais, que, no ámbito local, son as mellores voceiras do idearium das Irmandades. Como sostería Vicente Risco en máis dunha ocasión, tiña maior valor un irmandiño a título individual (fose o poeta Cabanillas ou o "xenial artista» Castelao) que toda unha agrupación local, porque o triunfo do galeguismo dependería máis «dunha novela notabre escrita en galego» que de «todol-os progresos materiás» (A Nosa Terra, 10.7.1918).

Durante os dous primeiros anos de existencia do movemento das IF, a rápida e sucesiva creación de círculos locais estivo acompañada de dúas tensións que se resolveron parcialmente na primeira Asemblea das IF, realizada en Lugo en novembro de 1918. A primeira tensión ten que ver co modelo organizativo dos irmandiños e coa necesidade de forxar unha estratexia compartida e un programa común. O degrau de afiliación dos integrantes das IF era baixo e, sobre todo, moi desigual. A IF da cidade da Coruña chegou a ter centos de militantes, mentres que outros círculos locais non pasaban da media ducia. Un pesimista Vicente Risco confésalle a Losada Diéguez, a finais de 1918, que na cidade de Ourense a Irmandade da Fala non ten máis de tres militantes, o que é «algo motivo de curiosidade, cando non de coña», e na visita que fai a Santiago de Compostela, dous meses máis tarde, «non [atopou] ningún que [o] levara á Irmandade nin que [lle] presentara» militantes xa coñecidos («famosos») como Xesús R. Culebras ou Francisco Vázquez Enríquez (Ventura 2010: 13 e 25). Á marxe destas impresións negativas, o certo é que as IF albergaban desde o inicio a vontade de ser un movemento e non un partido político, dado o escaso creto que os partidos tiñan na vida política daquela época. Un dos dirixentes máis sólidos daquela 
primeira hora das IF, Lois Porteiro Garea, afirma no verán de 1916 que «non [forman] un partido», porque este novo movemento non ten intención de «formar politicadas» e «[corromperse] andando aos votos e xogando a impia comedia dos diputados» (Seixas Seoane 2016: 36). A procura de votos foi tentada nas eleccións parlamentarias de febreiro de 1918, con catro candidatos presentados nos distritos de Pontedeume (Rodrigo Sanz), Noia (Vázquez Enríquez), A Estrada (Losada Diéguez) e Celanova (Porteiro Garea), que non lograron saír elixidos, malia o apoio e orientación estratéxica que lles prestou o catalanista Francesc Cambó para organizaren a campaña electoral e dispoñeren dun medio de comunicación como o xornal coruñés El Orzán (Beramendi 2007: 452 e ss.).

O fracaso electoral das IF acelerou a necesidade de se dotaren dunha mellor estrutura organizativa e de fixaren, ao tempo, un programa ideolóxico e político. O pulo organizativo foi obra do principal directivo da IF da cidade da Coruña, Lois Peña Novo, quen elaborou un regulamento que mudaba os obxectivos do movemento (incluíndo a autonomía política de Galicia) e abría o camiño para unha acción coordinada das IF. A plasmación desta iniciativa sería a primeira asemblea política das IF, realizada na cidade de Lugo os días 17 e 18 de novembro de 1918, na que se reúnen 60 persoas que representan 16 organizacións locais e que cambiou de vez o perfil político das IF (Beramendi 2007: 464 e ss.). As mudanzas producidas na asemblea de Lugo foron de carácter organizativo e político. No plano organizativo, a reunión de Lugo foi a primeira dunha serie de asembleas que, con periodicidade anual (Santiago, Vigo, Monforte), se realizaron ata febreiro de 1922, cando ten lugar unha escisión do movemento e un intento, comandado por Risco, de crear unha estrutura máis centralizada a través da Irmandade Nazonalista Galega, da que o ourensán sería elixido conselleiro supremo. A segunda consecuencia foi de carácter ideolóxico e político, ao se declarar pública e solemnemente: «[N]ós nomeámonos, de oxe para sempre, nazonalistas galegos». Era o final dun período de dous anos de incertezas, nas que a orientación ideolóxica das IF estaba entre o rexionalismo político de inspiración catalanista, o catolicismo social e o maurismo conservador. No sector 
máis moderado das IF (Antonio Valcarce, Rodrigo Sanz, Aurelio Ribalta, José García Acuña), a decisión tomada na asemblea de Lugo foi recibida con moitas críticas: «No asamos y ya pringamos», dille Ribalta a Valcarce unha semana despois da reunión de Lugo. O rexionalismo de tradición «solidaria», que soñaba aliarse con algúns sectores dos partidos «dinásticos», ficou cerrado co fracaso electoral de 1918 e coa incorporación plena ao movemento irmandiño do grupo da revista La Centuria (Ourense, 1917), nomeadamente de Losada Diéguez e, algo máis tarde, de Vicente Risco, que foi quen marcou a liña teórica -e mesmo organizativa- das Irmandadades da Fala desde 1918 ata a chegada do réxime de Primo de Rivera en setembro de 1923.

A laxa militancia que caracteriza as IF non abondou para que o número de integrantes das diversas agrupacións locais fose elevado. Na asemblea de Monforte, segundo os cálculos de Vicente Risco, deberían estar representados ao redor de seiscentos militantes, dado que se calculaba que a agrupación da Coruña, que tiña trescentos, supoñía a metade de todo o movemento irmandiño. En termos comparados, a militancia irmandiña era realmente baixa, pois a Gaelic League, cara a 1908, alcanzou a ter arredor de 47000 membros (Allegue 2017: 363), aínda que a poboación total de Irlanda en 1911 apenas duplicaba a de Galicia polas mesmas datas. O perfil sociolóxico das IF, con datos coñecidos de 433 militantes no período 1918-1924, revela que os sectores máis relevantes son os «profesionais liberais» da avogacía, a medicina e a técnica (25,6\%), os "propietarios e empresarios/comerciantes» (23,1\%) e os membros de actividades intelectuais (profesores, escritores e escritores/xornalistas), cun 22,6 \%. Entre estes tres sectores suman máis dun setenta por cento, o que explica a baixa militancia de persoas procedentes das "clases populares», pero tamén da Igrexa, o Exército ou a Administración civil. En conxunto, resulta evidente que a base sociolóxica das IF ten un «claro predominio de profesionais liberais e intelectuais», sector de onde proceden case todos os seus dirixentes ou "guieiros» (Beramendi 2007: 698 e ss.). En organizacións análogas, como a irlandesa Gaelic League, segundo análises de T. McMahon, a composición sociolóxica dos seus 
líderes cara a 1912 sería aínda máis mesocrática: un 47,2 \% de profesionais liberais e un 44,6\% de funcionarios, traballadores do comercio e artesáns (Allegue 2017: 364).

A educación formal da elite das IF era xeralmente universitaria (Dereito, Medicina, Letras, Maxisterio), con estadías en centros foráneos (Madrid, Deusto), como acontecía con frecuencia no caso irlandés, no que moitos dirixentes da "xeración revolucionaria» se formaron en Inglaterra ou en Francia. No entanto, a diferenza do exemplo irlandés, no que foi esencial o papel desempeñado polas escolas católicas dos Christians Brothers e por centros superiores como o University College de Dublín (1908) - «un microcosmos de sentimento político en Irlanda»-, onde se educaron ducias de membros da xeración revolucionaria (Paseta 1999: 53 e ss.; Foster 2015: 31 e ss.), nin os estudos secundarios nin tampouco os universitarios experimentaron en Galicia un proceso de adquisición de compromiso coa cultura e a lingua galegas, dado o afastamento da Igrexa católica a respecto do movemento rexionalista e, despois, das Irmandades. De modo parcial, este déficit formativo das elites das IF foi compensado por unha educación informal adquirida no xornalismo e, sobre todo, na emigración americana en Cuba e na Arxentina. En suma, foi o resultado dunha educación formal superior e da informal propia de «autodidactas, con formación adequirida nas loitas agrarias, societarias e nas aventuras da emigración» (Villar e Cabanillas 1977: 27). A base social dos militantes e dirixentes das IF galegas non era, pois, moi diferente á doutros movementos nacionalistas daquela época, de claro predominio de clases medias que eran a expresión dunha mobilidade social ascendente e de nivel cultural elevado. «La república de los poetas» é o título dun dos artigos sobre Irlanda publicados en El Sol por Ricardo Baeza, quen observa que nos primeiros postos da loita política dos Sinn Féiners se atopan poetas, dramaturgos, escritores e historiadores como Griffith, Rusell, Childers, Fitzgerald ou Green, por non mencionar «compañeiros de viaxe» como o insigne poeta William B. Yeats (Baeza 2010: 113 e ss.). En algo semellante debía pensar o romancista galego Otero Pedrayo, cando soña un perfil de "poeta e loitador feniano» 
-e non de avogado- para o protagonista do romance «O Estudante» (terceira parte da novela Os camiños da vida, de 1928), en esporádica viaxe ás terras irlandesas desde o seu exilio en París.

O programa das IF ten trazos claramente debidos aos textos fundacionais e á tradición anterior de «solidarios» e de agraristas. Pero tamén experimentou unha notable transformación a partir da primeira asemblea política, realizada en novembro de 1918, na cal se aproba formalmente a transición do rexionalismo ao nacionalismo político. Durante os dous primeiros anos de existencia, as IF concentraron os seus esforzos en dous grandes obxectivos, contidos no texto editorial do primeiro número de $A$ Nosa Terra (novembro de 1916), «A bandeira ergueita». O primeiro obxectivo é a defensa «agarimosa» do idioma galego, consonte coa propia denominación de seren «amigos» e «irmandades da fala». Colocando a cuestión da lingua en primeiro termo, as IF estaban a romper con toda a tradición cultural galega herdada do Rexurdimento, na que o emprego culto da lingua galega estaba reservada para o rexistro poético, mentres que na prosa, nas relacións familiares e epistolares ou nos mitins políticos era esporádico o uso do idioma. Esta aposta aspiraba a superar a herdanza, xa denunciada polos provincialistas románticos e por poetas como Rosalía de Castro, de ser a lingua popular un «marcador social negativo». A estratexia das IF trata de inverter o proceso e esta foi, sen dúbida, a súa principal achega á cultura galega contemporánea, dada a importancia que, desde o rexionalismo, se lle prestaba ao campo cultural (pero non tanto ao lingüístico). Nunha análise evolutiva dos contidos publicados na revista $A$ Nosa Terra, tanto nos tempos da Solidaridad Gallega como no das Irmandades, a hexemonía da cultura é constante, cunhas taxas de entre o $30 \%$ e o $35 \%$ na «distribución temática» dos artigos publicados, desde 1908 ata 1930 (Beramendi 2007: 353 e 649).

O programa político das IF experimentou mudanzas ou adaptacións co paso do tempo, dentro dunha estrutura estable resumida no «decálogo nazonalista», redactado por Vicente Risco a partir dos acordos da asemblea política de Lugo e logo publicado con diversos formatos e títulos no voceiro A Nosa Terra. 
Collendo como punto de partida este decálogo, alén doutros textos doutrinais coetáneos, podemos agrupar en tres capítulos os contidos programáticos das IF. O primeiro consiste na «regaleguización» de Galicia, entendida nun sentido análogo ao que trataron de facer os nacionalistas irlandeses, aínda que modulando a intensidade do proceso. No caso galego, a proposta central foi a recuperación do idioma galego como expresión dunha empresa "palinxenésica, redentora», como diría anos máis tarde Ramón Villar Ponte. Esta recuperación da «fala» debería ir acompañada dun programa de reconstrución da cultura galega no seu conxunto, pensada e expresada basicamente na lingua propia e a través dos máis diversos rexistros: cultivo literario, comunicación social, teatro e música coral e, por suposto, no ámbito institucional e político.

O obxectivo final, tamén análogo ao do proceso irlandés, era «descastelanizar» Galicia e, por tanto, «galeguizar» Galicia. Así como se procuraba construír unha «Irlanda irlandesa» a través dunha enérxica de-Anglicization, na que «ser irlandés significaba non ser inglés» (Paseta 1999: 120), o proxecto global das IF era lograr un monolingüismo galego que, en realidade, só foi practicado entre os propios militantes e simpatizantes das Irmandades. De feito, no mencionado decálogo, a cuestión lingüística só está presente nun dos dez mandatos (o terceiro), no que avogan por unha «cooficialidade dos idiomas galego e castelán», idea que continuará vixente ata o Partido Galeguista da II República. Con todo, o programa cultural das IF foi alén da propia cuestión lingüística. Os militantes irmandiños, tanto os máis liberaldemócratas do grupo coruñés como os máis tradicionalista-católicos do ourensán Grupo Nós, concedéronlle moita importancia á construción dun repertorio simbólico de carácter nacional galego. A este fin responden iniciativas como a fixación do 25 de xullo, festa do apóstolo Santiago, como Día Nacional de Galicia; a mitificación da figura histórico-lendaria do mariscal Pardo de Cela, capturado en 1483 polas tropas de Castela na súa torre da Frouseira, ou a resignificación de monumentos como o dedicado polos rexionalistas aos mártires de Carral, militares liberais que acaban convertidos en heroes das liberdades galegas, para formaren entre estes e aquel, como unha nova 
Vía Láctea, a «vía roxa que vai do Medulio á Frouseira e da Frouseira a Carral», en bela metáfora de Antón Villar Ponte ( $A$ Nosa Terra, 10.5.1917).

Un segundo bloque programático está constituído polo obxectivo de lograr para Galicia un status de autonomía política, por veces cualificada como integral, no marco dos debates que se estaban a dar en España nas primeiras décadas do século vinte. Este é o primeiro punto do decálogo, que, ademais, se reforza con outras reivindicacións, como a autonomía municipal e a igualdade de dereitos civís e políticos para homes e mulleres. O programa político das IF tiña, pois, dous piares nos que sosterse: converter Galicia nun suxeito político mediante a consecución dun réxime de autonomía integral e, en segundo lugar, superar as limitacións do liberalismo oligárquico do réxime da Restauración, cun combate ao clientelismo político (anticaciquismo) e unha vontade de rexeneración da vida política ou de adhesión ao que Ortega y Gasset chamaría naquela altura a «nova política», na que a cidadanía tiña un papel central. No entanto, os resultados políticos obtidos polas IF durante esta fase inicial, de 1916 a 1923, foron relativamente pobres. A participación na vida política reduciuse a simbólicas presenzas no ámbito municipal, con Lois Peña Novo como concelleiro na cidade da Coruña en 1920, posición que non era do agrado de militantes moi risquianos como o poeta Manuel Antonio. As tentativas de acceder á vida parlamentaria do Congreso dos Deputados ficaron bloqueadas nas eleccións de febreiro de 1918, polas razóns que logo veremos. Ata as eleccións constituíntes da II República (xuño 1931), o nacionalismo galego non volveu competir electoralmente, aínda que neste caso con mellores resultados ao acadar, en diversas listas electorais, catro deputados dun total de 47 elixidos en Galicia: Alfonso Castelao, Ramón Otero Pedrayo, Antón Villar Ponte e Ramón Suárez Picallo. Os propósitos de rexeneración política do sistema, especialmente no combate do clientelismo, que defendía unha parte importante das IF (aquela que procedía da tradición «solidaria» e federal), ficaron adiados ante a resistencia pétrea que tivo a estrutura política de Galicia, na que de 1876 a 1923 tan só un deputado, entre novecentos corenta e cinco electos, non pertencería aos dous partidos «dinásticos» (Villares 2005: 211). 
O terceiro bloque do programa das IF foi, sen dúbida, o que tiña un maior degrau de elaboración, porque procedía da corrente «solidaria», dos debates das asembleas agrarias de Monforte e do grupo da revista Estudios Gallegos. Refírome á política arancelaria ou, dito doutra forma, a defensa do librecambismo fronte ao proteccionismo propio da política económica de carácter nacionalista que comezou en España a partir de 1891, nunha viraxe que o propio Cánovas del Castillo se viu na obriga de explicar en varias conferencias pronunciadas no Ateneo madrileño (Serrano 1987). No caso galego, máis que un programa para solucionar o réxime foral e camiñar cara á propietarización do campesiñado (que era a bandeira do agrarismo de Basilio Álvarez), as IF adoptaron unha entusiasta adhesión ao ideario librecambista, o que, a determinada altura histórica, provocaría un forte desacordo con Francesc Cambó, como ministro de varios Gobernos de España en 1918 e 1921. O librecambismo das IF foi defendido por varios técnicos e reformistas agrarios (Bartolomé Calderón, Eloy Luis André, Valeriano Villanueva), pero, sobre todo, por Rodrigo Sanz nas asembleas agrarias de Monforte. Este librecambismo era especialmente insistente en conseguir a libre importación do millo como unha medida necesaria para o consumo alimenticio da poboación rural e, ademais, como penso para alimentación animal, o que permitiría facer competitivo o sector agropecuario de Galicia na súa estratexia de exportación de reses vacúas ás principais prazas de consumo de carne en España. Os argumentos librecambistas do nacionalismo galego están ben sintetizados na segunda asemblea agraria de Monforte (1910), de acordo co resumo feito anos máis tarde por Rodrigo Sanz: «En Galicia hace falta trigo y maíz [...], los hombres y el ganado necesitan mucho más maíz del que nosotros producimos» (Estudios Gallegos, 2, 1915). Nos seus cálculos estimábase que o sobreprezo destes produtos era de entre un $25 \%$ e un $28 \%$, isto é, que «unos cuatro millones de pesos anuales [pagaba] nuestro aldeano por el derecho de comer a diario su pan de centeno o de maíz».

Esta reivindicación do librecambismo arancelario non tivo percorrido político e institucional, tanto pola firmeza proteccionista da política económica 
española, acentuada aínda máis no arancel de 1921 promovido por Francesc Cambó, como polas contradicións que entrañaba esta demanda de liberdade aduaneira para unha economía agropecuaria que se estaba a inserir no mercado interior español, no que vendía milleiros de toneladas de carne producida en Galicia (Villares 1982). Pero tratábase dunha demanda que encaixaba perfectamente no ideario nacionalista e só algúns técnicos coetáneos, como Cruz Gallástegui, director da Misión Biolóxica de Galicia, revisaron ou denunciaron o que consideraban unha clara contradición, dado que era a agricultura española e non a galega a máis deficitaria na produción de millo: «Los españoles nos hacen hablar y Galicia habla y pide maíz para que se beneficien otras regiones» (Gallástegui 1930). O argumento máis acaído foi dado, nun texto técnico, polo economista do Banco de España Antonio Flores de Lemus, para quen non sería congruente comprar os pensos gandeiros a prezos do mercado exterior, como facían as agriculturas de Suíza, Holanda ou Dinamarca (que eran o espello no que se miraban os técnicos agronómicos galegos), "para vender sus productos en el mercado interior con el margen adicional de la protección arancelaria», ao que podería engadirse que a importación de millo estivo liberalizada realmente ata 1926 (Flores de Lemus 1926; Jiménez Blanco 1986: 255).

As Irmandades galegas foron fundadas de maneira tardía, en comparanza cos modelos coetáneos catalán e vasco, e tamén tardaron en se dotar do instrumento político dun partido, que non chegou ata 1931, cando se funda o Partido Galeguista, en pleno réxime republicano. Pero a obra das IF foi esencial para configurar o moderno nacionalismo galego, porque foron quen de cuñar un proxecto político novo, que rompía non só co vello rexionalismo, senón tamén coa «vella política» do liberalismo español. As súas forzas eran limitadas e a capacidade para formular un proxecto político interclasista e de masas non foi posible ata os tempos da II República. Pero a fase fundacional das Irmandades da Fala, de 1916 a 1923, foi importante por dúas razóns. A primeira, porque elaboraron os fundamentos ideolóxicos e doutrinais de Galicia como unha nación, na que a reivindicación da lingua galega foi esencial, como o seu propio nome 
indica. As IF tentaron crear unha conciencia nacional a partir da identidade cultural. A segunda achega importante foi a de considerar o caso de Galicia dentro do contexto ibérico e mesmo europeo, procurando deste modo alianzas externas e complicidades que visibilizasen o feito nacional galego.

\section{INTERNACIONALIZAR O NACIONALISMO GALEGO}

As Irmandades nacen, como expresan textos e artigos de varios dos seus dirixentes (Antón Villar Ponte, Viqueira, Risco), cunha visión «internazonalista», no sentido de procurar alianzas con movementos políticos e culturais que se podían considerar análogos ou próximos aos de Galicia. Esta conexión co exterior foi pensada basicamente en tres direccións: nas relacións dentro do Estado español con vascos e, sobre todo, cataláns como unha continuidade da época da «España regional»; en segundo lugar, construíndo con Portugal un referente de reintegración cultural que, de paso, servise de intermediación para entrar nalgúns circuítos culturais europeos, nomeadamente franceses, e, en terceiro lugar, conectando co exemplo máis emblemático de loita nacional daquela época, que foi Irlanda. Malia que os dirixentes das IF eran plenamente conscientes de que precisaban apoios e relacións exteriores que reforzasen a súa acción interior, en especial para definiren mellor a súa estratexia política, os resultados conseguidos foron escasos, tanto dentro da Península Ibérica como nas posibles relacións con Irlanda ou na incorporación a plataformas europeas como a Union des Nationalités ou a organizacións pro Liga das Nacións, como as catalás Amics d'Europa ou a revista Messidor (Núñez Seixas 2010: 64 e ss.).

A demora con que apareceron as IF impediu claramente que o cuestión nacional galega se incorporase á euforia wilsoniana de 1918. Un punto esencial foi a ausencia de estratexia específica a respecto da guerra europea, da que apenas se encontran máis que fuxidías mencións nos textos e nos xornais de orientación irmandiña, e tamén respecto da Liga das Nacións, á que algún Concello galego 
dirixe unha saudación, pero sen que se pense tan sequera en enviar unha delegación á reunión de París que se ocupou dos tratados de paz desde novembro de 1918. Isto representaba un contraste enorme co que sucedía no caso de Cataluña, cun pequeno corpo de voluntarios enviados á fronte bélica e algunha tentativa de estar presente nos tratados de paz e poder aproveitar a condición do mariscal francés Joseph Joffre como un "catalán do norte» con raíces na cidade de Reus, que sería recibido de forma entusiasta en Barcelona ao pouco de acabar a guerra. O mesmo se podería dicir de Irlanda, cuxa poboación (nomeadamente, a do Ulster) participou nos campos de batalla contra Alemaña, pero tamén, por parte dos «fenianos», procurando un apoio dos imperios centrais que logo debilitaría as súas aspiracións a estaren presentes nos tratados de paz de Versalles. A guerra foi, porén, unha oportunidade para proxectar internacionalmente a cuestión irlandesa, a través de figuras como Roger Casement, aliado de Alemaña que acabaría sendo fusilado polo Reino Unido, condenado polo delito de traizón.

Ademais, a guerra europea non só dividiu as sociedades belixerantes, senón tamén as neutrais e aquelas que, sendo subestatais, se atopaban en loita pola súa independencia. Como lembra o irlandés Cruise O’Brien, dous familiares seus morreron case coetaneamente, un na batalla de Somme (Thomas Kettle) loitando cabo dos aliados e outro (Francis Skeffington) loitando pola independencia de Irlanda durante o Easter Rising (O’Brien 1999: 14 e ss.). Algo semellante acontece en Cataluña, onde a guerra tamén afecta claramente ao campo do nacionalismo, con posicións máis xermanófilas, como as de Prat de la Riba, e máis aliadófilas, como as do republicano Rovira i Virgili. Este autor defendeu sen arrodeos a oportunidade de vincular o principio das nacionalidades coa loita pola liberdade e o progreso que representaban as potencias aliadas, de acordo co principio de que «todo nacionalismo teña unha política internacional», ou sexa, unha diplomacia propia (Núñez Seixas 2010: 34 e ss.). En calquera caso, a guerra europea foi tamén unha "guerra de papel» en países que, como España e Portugal, incialmente non estaban vinculados a ningunha das grandes alianzas europeas. Como é sabido, España mantívose neutral de modo permanente 
durante toda a guerra, mentres que os republicanos portugueses, representados por Afonso Costa e por líderes máis belixerantes como João Chagas, pugnaron por entrar na guerra da parte dos aliados para aseguraren o futuro do seu imperio ultramarino, cobizado polo rei español Afonso XIII (Torre Gómez 2002).

No caso dos nacionalistas galegos, a discusión sobre as súas alianzas exteriores non foi formulada abertamente ata despois da asemblea realizada en Lugo, que abriu unha porta de "pangaleguismo» cara a Portugal que sería ampliada a outros parceiros en asembleas posteriores. Como «temas indispensables a tratar» propuña Vicente Risco en xaneiro de 1921, nunha carta a Losada Diéguez, varios puntos que deberían ser discutidos na terceira asemblea das IF, que se ía realizar en Vigo no mes seguinte: «Autitude frente a Irlanda», «Relaciós con Portugal», «Relaciós con Vasconia e Cataluña» (Ventura 2010: 80). Tal elenco temático permite examinar estas relacións para calibrar o degrau de internacionalización do nacionalismo galego ata 1923 e avaliar as súas propostas en termos comparados.

As primeiras relacións externas que tratan de establecer as IF, na etapa de orientación propiamente rexionalista, foron co rexionalismo catalán que daquela lideraba Francesc Cambó. Eran unhas relacións pensadas no marco dunha estratexia política estatal de combate do sistema político da Restauración, na que o líder catalán estaba especialmente empeñado a partir da formulación do proxecto da Espanya Gran (1916) e da profunda crise política de 1917. Pero estas relacións co rexionalismo de Cambó pasaron en pouco tempo da euforia á desilusión. Certamente, existía en Galicia unha forte corrente de simpatía cara a Cataluña, patente nos tempos do rexionalismo finisecular, con viaxes de Brañas e Murguía a Barcelona, que aínda mellorou coa aparición de Solidaridad Gallega, que fixo do exemplo catalán un referente político e un modelo que seguir: "Hay que imitar a Cataluña», dicíase na Revista Gallega de 1907 (Beramendi 2007: 403). Esta conexión catalá foi retomada no momento fundacional das IF, cando aínda se debatían entre posicións rexionalistas e nacionalistas. No ano 1917 as IF establecen contacto coa Lliga de Cambó, o que dá lugar a unha viaxe de dirixentes galegos a Barcelona en novembro de 1917, como devolución 
dunha visita previa de Cambó a Galicia. O punto culminante daquelas relacións produciuse con ocasión das eleccións de febreiro de 1918, nas que Cambó soñaba con ser «Presidente del Consejo con unas Cortes adictas» e máis de «150 diputados» de sensibilidade rexionalista, pero aquel soño de romper a estrutura política da Restauración acabou nun completo fracaso, despois de non se obteren máis que 25 deputados, entre eles ningún procedente de Galicia (Riquer 2013: 93 e ss.).

Desde aquel momento, o nacionalismo galego deixou de ter interlocución coa Lliga e con Cambó, sen que fosen substituídos de inmediato por outros parceiros como Acció Catalana, ata que en setembro de 1923 se organiza de modo efémero a «Tripla Alianza», precedente do pacto Galeuzca de 1933 (Estévez 1991). O fracaso electoral de 1918 deixou un panorama de terra queimada. A entrada de Cambó en diversos Gobernos da monarquía (1918 e 1921) acelerou a oposición ás leis de protección arancelaria que o ministro catalán promoveu, o que supuxo unha campaña de desprestixio de Cambó, alcumado por Vicente Risco de «roñoso xudío»e de «nefasto ex-catalán» (Ventura 2010: 117), campaña que tamén comezou a ser patente no campo do nacionalismo catalán, apelando asemade a unha crítica de tons antisemitas (Ucelay 2008: 87-88). Incluso por parte do sector rexionalista e moderado das IF, a alianza catalá colócase en sordina, como acontece cando pensan, en alianza co «romanonista» Leonardo Rodríguez, en concorrer ás eleccións de 1919: o dirixente José García Acuña advirte, nunha carta desde Madrid de maio de 1919, ao seu amigo político Antonio Valcarce, que o mellor é "que los catalanes apoyen sin ir a Galicia para nada [sic]». Das relacións con Vasconia, como suxería a orde do día da asemblea das IF de 1921, apenas hai rastros ata a Tripla Alianza de 1923, malia a influencia que un «euskarófilo» como Losada Diéguez exercía no movemento das Irmandades.

Máis relevantes foron as relacións tecidas polos nacionalistas galegos con Portugal, que se concretaron en dous planos diferentes. O primeiro plano, máis claramente político, consistiu na conversión de Portugal nun referente positivo 
de reintegración, fundado na irmandade cultural e lingüística e tamén na oportunidade que abría o réxime republicano portugués para unha futura república federal ibérica. Villar Ponte, que recoñece que «fue en Lisboa y Oporto donde [su] pensamiento [o das IF] se robusteció», defendía tanto o "pangaleguismo» como un «iberismo integral», que traduciu nun dos acordos máis coñecidos da asemblea de Lugo: «Galiza ten que considerar a Portugal, pois elo é axiomático, como o baluarte da sua independenza espritoal» (A. Villar Ponte 1971: 211). Esta apelación a Portugal, que permitía servir de contrapunto ao referente negativo que era Castela, foi unha das correntes máis sólidas do nacionalismo galego contemporáneo, corrente que acadou na obra de A. R. Castelao Sempre en Gali$z a$ a manifestación máis acabada, ao considerar Portugal como expresión do que puido ser a propia Galicia. Nesta aposta lusitanista, de folgo republicano e federal, foi moi activo o grupo corunés das Irmandades, a través da obra xornalística e ensaística de Antón Villar Ponte ou de Xohán Vicente Viqueira, que defenderon tamén unha aproximación, mesmo ortográfica, da lingua galega á portuguesa. Incluso un intelectual algo distante das IF, como Eloy Luis André, defendía a vixencia da lingua galega por ser un idioma universal: «Non pode morrere unha lingua que empregan trinta millós de persoas» (A Nosa Terra, 25.1.1917). Nas páxinas do voceiro $A$ Nosa Terra son moi frecuentes as noticias e alusións referidas á cultura e á política portuguesas e algún dirixente, como o ministro Leonardo Coimbra, fixo unha visita a Galicia por convite da Irmandade coruñesa. En calquera caso, esta aproximación a Portugal tivo poucos ecos no país veciño, onde non se chegou a crear ningún movemento de carácter irredentista que reclamase unha unión política galaico-portuguesa, agás en poemas como « $\mathrm{A}$ Galiza. A modo de velho cantar», do poeta A. Lopes Vieira: «[D] eixa Castela e vem a nós!», do cal se fixo eco o voceiro das IF (A Nosa Terra, 10.09.1917). Murguía aludira no seu tempo á indecisión portuguesa e, en 1920, unha viñeta de Castelao volvía sobre a mesma idea cando un avó non soubo dicirlle ao seu neto que falaban os que moraban alén do río Miño. Irredentismo case inexistente en Portugal e reintegracionismo máis cultural que político en Galicia eran as caras dunha moeda que apenas puido ter circulación. 
O reintegracionismo cultural é o segundo plano de relación con Portugal, desenvolvido de forma prioritaria polo Grupo Nós e, nomeadamente, por Vicente Risco, quen confesa en 1921 a Pascoaes: «Teño prenos poderes da Asambreia das Irmandades [realizada en Vigo] pra m'entender cos nosos amigos de Portugal» (Cameirão 2010: 465). Esta relación concretouse na forxa dunha alianza cultural con autores e revistas portugueses que permitisen unha presenza da cultura literaria galega non só en Portugal, senón tamén, pola súa intermediación, en publicacións francesas. O principal interlocutor portugués foi o poeta Teixeira de Pascoaes, director da revista A Águia e líder do grupo intelectual Renascença Portuguesa (1911), a quen Risco saúda como «confrade e amigo» no seu epistolario cruzado. Grazas a esta relación, estableceuse unha colaboración regular de autores galegos en revistas portuguesas e á inversa, á que contribuíu o propio Pascoaes cun texto poético publicado no primeiro número da revista Nós. Pero o más importante foi a conexión co crítico literario francés Philéas Lebesgue, colaborador habitual na revista Mercure de France, na que de forma periódica foi dando noticia da cultura galega na sección «Lettres portugaises», desde 1920 ata 1936 (Figueroa 1996). Aínda que se trataba de relacións mediadas por Portugal, o certo é que as obras de autores galegos, desde Rosalía a Noriega Varela, Bouza-Brey, Ramón Cabanillas ou o propio Risco, foron difundidas a través desta revista francesa. Tal conexión literaria entre a revista Nós e Lebesgue, con Teixeira de Pascoaes de mediador, ilustra este esforzo de internacionalización que leva a cabo o nacionalismo galego, fundado nun común substrato celta que tamén compartía o propio Lebesgue, xustamente considerado por Risco como «o valedor da nosa literatura na Francia erudita» (Nós, 30.10.1920).

O referente exterior máis importante para o nacionalismo galego, no que tamén estaba presente unha remota irmandade céltica, foi Irlanda, o espello que cativou as olladas da maioría das nacionalidades europeas, como no século XIX o fixera Polonia. A presenza da cuestión irlandesa en Galicia tivera certa importancia no rexionalismo galego finisecular, cando algúns autores como o notario Diego Pazos ou o dirixente rexionalista Alfredo Brañas seguiron con atención as 
loitas agrarias irlandesas que levaron á Land Act de 1881, as cales transformaron a estrutura da propiedade da terra en favor dos colonos católicos, pero penalizaron o «protestante» Parnell como dirixente político (O’Brien 1994: 52). O moi invocado texto poético do rexionalista galego Alfredo Brañas, apelando ao exemplo irlandés como modelo para os campesiños galegos ( «iErgue labrego! ${ }_{i}$ Érguete é anda! [...] / ¡Coma en Irlanda! ¡Coma en Irlanda!»), forma parte dunha conexión irlandesa que non tivo continuidade ata moi andado o periplo das Irmandades da Fala. Pode dicirse que o espello irlandés, malia o apoxeo do paradigma do celtismo na formación da idea de Galicia por Manuel Murguía, entrou nun Guadiana do que non saíu claramente ata 1920, catro anos despois de ter lugar o Easter Rising de Dublín. As noticias sobre Irlanda en A Nosa Terra durante os anos que transcorreron de 1916 a 1923 foron «unha crónica de ausencias, paixón e silencio», como sostén un estudoso do caso (Madriñán 2017: 201), e, engadiriamos pola nosa parte, tamén de viraxes inesperadas máis debidas a conflitos internos que a unha coherencia ideolóxica coas fraccións do nacionalismo irlandés. Ignorancia ou estanquidade de procesos políticos que, en cambio, non se rexistra en contextos algo análogos, xa non só en Cataluña, onde a cuestión irlandesa estivo moi presente na evolución do nacionalismo catalán, no que o Easter Rising tivo «un impact incalculable» (Ucelay 1984: 218), senón mesmo na Bretaña, onde algúns dos seus dirixentes (François Debauvais) pasaron noites de insomnio naquela Pascua de 1916, á espera de noticias de Irlanda, ou fixeron pintadas nalgún muro de Rennes (Carney 2016: 77 e ss.; Le Cloarec 2016: 60). No caso galego, non consta que Villar Ponte ou os seus amigos fixesen tal cousa en ningunha cidade galega, malia que dispuñan dun «coñecimento suficiente dos últimos acontecimentos na Irlanda», dado que estaban a ser publicados na prensa galega coetánea (Madriñán 2017: 202).

No entanto, o interese do nacionalismo das IF pola evolución política de Irlanda foi forte a partir de 1920, no contexto da hexemonía política do Sinn Féin, os conflitos arredor do tratado de 1921 e a guerra civil posterior. Houbo tres aspectos da política irlandesa que cativaron de forma especial os nacionalistas 
galegos, porque dalgún modo empataban coas divisións internas que estaban a experimentar as IF e que se fixeron explícitas na escisión da asemblea de Monforte de 1922: o debate sobre nacionalismo político ou cultural, que se encontra na polémica entre Lois Peña Novo e Vicente Risco; o conflito entre «tratadistas» e «antitratadistas» ou, dito doutro modo, entre os Home Rulers de Redmond e os separatistas do Sinn Féin e, en terceiro lugar, os efectos da violencia política e a «mística sacrificial» que comezara cos mortos de Pascua, seguiu coa morte do alcalde de Cork e culminou coa guerra civil e os seus devastadores efectos en tantas familias, como ao seu modo rexistra o texto que antepón Xosé Filgueira Valverde a un dos seus primeiros escritos, Os nenos, adicado aos nenos irlandeses que ficaran orfos tras a guerra civil. Sen entrarmos na peripecia seguida pola «xeración revolucionaria» irlandesa, importa anotar a recepción que tivo aquel proceso e os ecos del que chegan a Galicia.

Estes ecos irlandeses foron bastante tardíos, malia a irmandade celta que unía os dous pobos. Nin os conflitos provocados pola propia guerra europea nin a viraxe producida en 1916 co Easter Rising e a posterior eliminación do nacionalismo «constitucional» defendido polo Partido Parlamentario Irlandés de Redmond, que levou ao esmagador triunfo dos republicanos do Sinn Féin nas primeiras eleccións da posguerra (73 deputados «fenianos» fronte a 6 deputados «redmondistas»), tiveron unha repercusión especial en Galicia. Probablemente non era por ignorancia, porque na propia prensa galega ( $\mathrm{La}$ Voz de Galicia, El Noroeste) e na de Madrid (El Sol) ou Barcelona (La Vanguardia) apareceron noticias e artigos de autor sobre a cuestión irlandesa. Abonde mencionar a penetrante serie de artigos de Ricardo Baeza, publicados en El Sol durante os anos 1920 e 1921, nos que se fai unha irónica alusión aos fillos de Breogán, descubridor de Eirín: «Los gallegos están moralmente obligados a interesarse por el futuro de Irlanda, cosa que a pesar de las misas celebradas por el finado alcalde de Cork, tememos no hayan hecho lo bastante hasta el presente» (Baeza 2010: 104).

Foi a partir de 1920 cando as IF, unha vez xa definidas como nacionalistas, comezaron a prestar atención á política irlandesa, radicalizada despois do Tratado 
de Versalles e liderada polos republicanos Sinn Féiners, que rexeitaban a política parlamentarista e apostaban pola independencia de Irlanda do Reino Unido. Durante os anos 1920-1923, as publicacións nacionalistas galegas (A Nosa Terra e $N o ́ s$ ) incorporan extensas noticias sobre asuntos irlandeses, quer sobre a súa literatura e historia, quer sobre un episodio que alcanzou enorme eco na vida pública europea: a folga de fame e ulterior morte no cárcere do alcalde de Cork, Terence MacSwiney, acontecida en outubro de 1920, entre un «sorprendente» apoio da Igrexa católica -había dúbidas teolóxicas sobre se era realmente un suicidio- e reservas sobre a súa actitude por parte de persoas máis próximas, como Michael Collins ou a súa muller, Muriel, que non concordaban de todo con aquel sacrificio persoal de «morrer por Irlanda» (Baeza 2010: 172 e ss.; Foster 2015: 273 e ss.). Pero, un ano máis tarde, a revista Nós (núm. 8, decembro de 1921) dedicou un número enteiro á memoria do mártir irlandés, con apuntamentos biográficos de Losada Diéguez, unha biografía escrita pola irmá de MacSwiney que Risco dicía «estar traducindo do inglés» (Ventura 2010: 119) e poemas de Cabanillas ou Victoriano Taibo. Con todo, a principal contribución foi a tradución, debida a Antón Villar Ponte, da obra de William B. Yeats Cathleen Ni Houlihan, expresión literaria, en palabras do seu tradutor, de «las luchas de un país hermano del nuestro para independizarse de un imperialismo extraño» (Ínsua 2005: 196-197). A aposta da revista Nós era unha auténtica homenaxe, despois de anos de indecisión sobre que camiño seguir no enfoque da revolución irlandesa, e como unha forma de promocionar a causa galega no exterior. Deste número da revista envían cen copias á delegación irlandesa en Madrid "para mandar a Irlanda» e tamén se comprometen a vender retratos do alcalde de Cork para recadar diñeiro con destino á Cruz Branca irlandesa.

Esta posición de Nós, que en parte se afastaba da mantida por A Nosa Terra, conectaba claramente cos debates internos das IF, que, no mes de febreiro de 1922, realizarían unha decisiva asemblea política que levou á escisión do movemento. A escisión podería entenderse, mutatis mutandis, como unha versión galega da ruptura entre os partidarios do tratado, cos que simpatizaba o grupo 
da Irmandade coruñesa, e os republicanos dirixidos por De Valera, aos que se sentía máis próximo o Grupo Nós. A atención prestada pola revista á cuestión irlandesa era tamén o resultado dun intenso labor de comunicación, mesmo por vía diplomática, cos representantes irlandeses en Madrid, nos que actuou de eficaz intermediario un mozo galeguista, daquela escolante en Madrid: Fermín Penzol (Cabrera 2016: 62 e ss.). Vicente Risco tivo especial coidado en manter baixo control as relacións coa delegación irlandesa en Madrid, para evitar a intromisión dos defensores do «tratado noxento», informar da situación política de Galicia («Mandeille a O’Brien unhas notas longas escritas en francés», dille Risco a Losada) e revalidar o apoio ás posicións de Éamon de Valera. Os ecos de Irlanda podían ser ouvidos en clave interna galega sen que, en dirección inversa, sucedese algo análogo. Alén desta descompensación, cómpre ter en conta un feito esencial: que as relacións de «afinidade» (celtismo, opresión externa, emigración...) non abondan para forxar unha alianza política, porque «só se pode configurar outra nación como semellante unha vez que se procedeu previamente á definición da propia» (Madriñán 2010: 18).

O esforzo feito polas IF, en especial por Vicente Risco, para colocar a cuestión do nacionalismo galego na axenda internacional foi meritorio pero moi limitado, o que non lle quita valor á sentenza risquiana de 1921: «Nós, sen apoio fóra, nada poderemos endexamais» (Ventura 2010: 94). A conexión exterior funcionou mellor a través de contactos persoais, como os mantidos con Teixeira de Pascoes ou Philéas Lebesgue, e menos en niveis institucionais, agás a esporádica relación cos cataláns. A súa debilidade organizativa non lles permitía chegar aos grandes foros europeos onde se debatían as cuestións das nacionalidades ou das minorías nacionais. Non existían medios materiais para logralo (sen figuras como o catalán Cambó ou o vasco De la Sota), nin o arraigamento social do nacionalismo en Galicia era comparable aos casos de Vasconia e de Cataluña nin, por descontado, ao de Irlanda. Esta proxección exterior do nacionalismo galego só acadaría unha certa dimensión nos tempos da II República e, logo, durante o exilio republicano, con actores procedentes das primeiras Irmandades, 
como Castelao, e outros, máis novos, como Plácido Castro, que, con todo, non chegaron a desempeñar en Galicia un papel análogo ao do mallorquino Joan Estelrich.

\section{UN BALANCE: APOSTAS E BLOQUEOS}

Un balance final sobre tres aspectos clave pode servir de recapitulación destas páxinas e tamén de reflexión en clave comparada. En primeiro termo, é preciso avaliar en que medida hai continuidade ou ruptura na "xeración galega de 1916» a respecto dos seus devanceiros; en segundo lugar, as razóns da hexemonía do nacionalismo cultural sobre o político, que separa o caso galego dos exemplos próximos de Vasconia ou Cataluña, pero, sobre todo, de Irlanda, e, por último, é preciso responder á interrogante de Risco, formulada en 1930, sobre a non-confluencia dos que el consideraba os dous partidos propiamente galegos, o nacionalista («en germen») e o agrario («malogrado»). Nese punto cego resumíase a diagnose do problema político de Galicia, feita no annus mirabilis de 1930 por quen era o principal responsable teórico e organizativo do nacionalismo cultural de Galicia.

Ruptura ou continuidade? O protagonismo das primeiras Irmandades foi debido a un pequeno grupo de persoas que poderiamos identificar como a xeración de 1916, de acordo co testemuño posterior de Ramón Villar Ponte (1977). Os seus principais integrantes eran xente moza, nacidos na súa maioría na década dos oitenta e, xa menos, dos noventa do século dezanove. Foi unha xeración que se podería equiparar, no seu perfil sociolóxico, ás que protagonizaron outras viraxes decisivas, como a xeración de 1901 en Cataluña, definida como tal por Gaziel, que estaba composta por membros algo máis experimentados que os das IF; á xeración española de 1914, marcada polo liderado de Ortega y Gasset, ou, no caso irlandés, á xeración de 1916, que foi a protagonista do máis grande xiro daquel tempo na Europa occidental, responsable de que all changed, changed 
utterly, no poderoso verso de William B. Yeats. O que marca todas estas xeracións é teren compartido experiencias intensas, como algunha guerra (1898, 1901, 1914), e propoñérense reaccionar contra os seus predecesores e contra a época que lles tocou vivir. Pero este desacougo epocal acadou unha intensidade temporal e un significado ideolóxico moi desiguais.

No caso da guerra europea, a influencia sobre a xeración das Irmandades foi case irrelevante, pero, en cambio, son plenamente conscientes de que deben diferenciarse dos seus devanceiros, aínda que con matices. Para Antón Villar Ponte, compañeiros xeracionais como Porteiro ou Viqueira poderían ser definidos como «continuadores» dos "precursores», daqueles que definira Murguía como protagonistas do Rexurdimento cultural e literario galego, pero o patriarca, porén, non é citado no manifesto fundacional das IF. Por outra banda, varios membros da Xeración Nós que elaboraron un relato da súa formación intelectual, como Otero Pedrayo ou Risco, non recoñecen propiamente un maxisterio anterior de autores galegos, aínda que non carezan de mestres, que acabaron encontrando na corrente cultural europea que vai do Romanticismo á «revolución conservadora» finisecular (Villares 2018: 193 e ss.). En suma, a autopercepción dos protagonistas das IF está máis próxima á ruptura que á continuidade. Alén da opinión de Risco, o propio Antón Villar Ponte non deixou de subliñar a súa iniciativa de maio de 1916 como «o mais grande e outo [acontecemento] que se fixo na nosa terra», porque "gracias a [eles, os promotores da primeira IF], os [seus] fillos terán unha patria» (A Nosa Terra, 30.05.1918). A peculiaridade do caso galego está, sen dúbida, na debilidade organizativa e mobilizadora do rexionalismo finisecular, que chega á crise do 98 nunha situación de atonía teórica e programática. Pola contra, a xeración catalá de 1901 defínese como alternativa a un rexionalismo conservador que estivo implicado na dinámica política do sistema da Restauración ata o batacazo de 1898, de cuxas consecuencias se afasta, como pon de relevo o coñecido poema de Joan Maragall «Oda a Espanya». E a xeración revolucionaria irlandesa foi o resultado dunha intensa «radicalización, polarización e colisión» desenvolvida desde 1890 
ata a explosión de 1916, na que se combinou unha intensa acción política e mesmo parlamentaria cunha reconstrución cultural en clave católica e irlandesa (Riquer 2001: 185 e ss.; Foster 2015: XV).

Un nacionalismo con «dúas almas», cultural e política? De certo, nas apostas estratéxicas das IF pode advertirse a existencia desde 1918 desas "dúas almas», tan frecuentes nos partidos nacionalistas contemporáneos. Inicialmente, advírtese unha tendencia cara á acción política e á intervención nos procesos electorais, que defende sobre todo un sector da Irmandade coruñesa, que conectaba coa experiencia catalá da Lliga e, doutro modo, coa experiencia irlandesa da loita parlamentaria a favor do Home Rule por parte do partido parlamentario de Redmond. Eran os que Risco chamaría despectivamente os «redmondistas» galegos. Esta aposta pola política saíu perdedora da asemblea de Monforte, como se puxo de relevo no debate posterior sobre unha «disparidade fundamental»: se o nacionalismo é un "problema de cultura» (Risco) ou un "problema de libertades» (Peña Novo). A posición de Risco e de moitos outros membros das IF, de Villar Ponte a Castelao, foi que era prioritario «facer un pobo» e crear "unha forte conciencia nacional que [os enxebrizase] totalmente», renegando con claridade do exercicio da política no marco do réxime liberal oligárquico da Restauración. Dito con palabras algo altisonantes de Antón Villar Ponte, trataríase dunha diverxencia entre os partidarios da «vitoria do ideal» e os que preferían o «ideal da vitoria», idea que o propio dirixente irmandiño xa expresara uns meses antes ( $A$ Nosa Terra, 15.07.1921), cando aludía a «duas crases de galeguistas», os de «temperamento apostólico» e os de «temperamento político». Neste debate percíbense claramente os ecos de disputas análogas en Cataluña ou en Irlanda, pero coa diferenza de que, sobre todo no caso irlandés, a vitoria do ideal non estaba separada da loita política e mesmo bélica contra o Imperio Británico. A converxencia destas dúas almas do nacionalismo galego será a tarefa relevante que fará unha nova xeración política, a que se forma no Seminario de Estudos Galegos, que marca as pautas do Partido Galeguista, fundado en decembro de 1931. 
Confluencia do nacionalismo co agrarismo? Esta aposta remite ao problema verbalizado de maneira tardía por Vicente Risco sobre os camiños que poderían seguir no futuro -e que, como é obvio, denuncia que non percorreran no pasado- os dous partidos que, na súa perspectiva, poderían chamarse propiamente galegos, o agrario e o nacionalista: «Si el agrario es un partido gallego malogrado, el nacionalista es un partido gallego en germen. De la integración de ambos debe formarse un día -si los labradores gallegos llegan a despertar y darse cuenta de sus verdaderos intereses- la fuerza política que defienda los de la región» (Risco 1930: 212). Dos desexos de Risco e dunha posible historia contrafactual non é do caso ocupármonos aquí. O relevante é analizar por que esa integración non tivo lugar nos anos fundacionais das Irmandades e que bloqueos produciu esa ausencia de entendemento entre un poderoso movemento agrarista e o nacente movemento nacionalista. Tamén neste caso, o espello irlandés pode axudar a entender o asunto galego, co que se atopan algunhas semellanzas mutuas: unha loita pola terra dos colonos católicos contra os grandes terratenentes protestantes e unha intensa propietarización campesiña que estivo acompañada dun forte éxodo rural. Pero o que resulta evidente é que os ritmos e os logros de ambos os procesos foron moi diferentes.

No caso de Irlanda, a "guerra pola terra» (Land War) favoreceu non só unha intensa mobilización social, senón tamén a penetración do nacionalismo no mundo rural ao se producir unha substitución do partido liberal inglés polo partido parlamentario irlandés, a partir das eleccións de 1885. Foi o principio dunha loita política polo Home Rule que chegou ata as vésperas da Gran Guerra, cando unha segunda viraxe abre o camiño á hexemonía dos «fenianos» e, por tanto, á loita pola independencia de Irlanda do Reino Unido. As analoxías do caso galego con este panorama son apenas formais. Existe en Galicia, desde a crise finisecular, un «malestar agrario» que provoca a aparición das primeiras organizacións agraristas (57 «mutuas gandeiras» e «sociedades de agricultores» fundadas ata 1900), pero non se produce a conexión entre agrarismo e acción política parlamentaria, malia as tentativas de figuras como Portela Valladares 
(elixido en 1905 como deputado liberal no distrito «agrario» da Fonsagrada) ou do abade Basilio Álvarez, promotor das máis importantes organizacións agraristas desde 1907 (Acción Gallega, 1912, e Confederación Regional de Agricultores Gallegos, 1922).

A retórica rexeneracionista dos dirixentes agraristas e o peso exercido polo reformismo técnico da agricultura galega, plasmado nas Asembleas Agrarias de Monforte, mantiveron o agrarismo lonxe non só do rexionalismo galego, senón mesmo do liberalismo español. A etapa máis madura e intensa do agrarismo galego foi a dos anos 1918-1923, cando se rexistra tanto unha densa rede asociativa, con cerca de mil organizacións (sindicatos, sociedades, ligas...), que representan o $15 \%$ das de toda España, como unha forte capacidade mobilizadora, co impago de rendas forais e a loita pola supresión dos foros, pola vía abolicionista ou a redencionista (Cabo 1998; Domínguez 2005). Malia esta coincidencia temporal, son poucos os contactos entre agrarismo e nacionalismo, de modo que non tivo lugar unha permeabilidade entre ambos os movementos, nin o agrarismo logrou erosionar a fortaleza electoral dos grandes partidos dinásticos (Conservador e Liberal). Pero o que resulta máis sorprendente é comprobar que o programa agrario das IF era tan dependente de asuntos como o librecambismo e a «libre importación de millo» que se esqueceu de afrontar a cuestión central, que era a reforma da propiedade da terra e a integración da pequena labranza no mercado, aspectos nos que as organizacións agraristas foron especialmente eficientes.

Foron, pois, diverxentes os camiños seguidos por nacionalistas e agraristas galegos, como apuntaba a diagnose de Vicente Risco en 1930. Pero do que non era consciente o antigo «conselleiro supremo» da Irmandade Nazonalista Galega era da forte limitación que esta diverxencia supuxo para o nacente nacionalismo, polo menos en aspectos esenciais. $\mathrm{O}$ nacionalismo perdeu a capacidade mobilizadora da poboación rural que posuía o agrarismo, así como o liderado exercido no ámbito local por emigrantes «retornados», que os nacionalistas desprezaban por seren «chés» ou «filisteos» incultos. Tamén se viu privado do concurso da 
Igrexa, que, pola contra, era moi forte na dirección do agrarismo, no que controlaba centos de sindicatos católicos, encadrados nas Federacións Católico-Agrarias galegas e na Confederación Nacional Católico-Agraria (Martínez 1995). E, finalmente, unha ausencia moi evidente no campo do nacionalismo: a «mística sacrificial» e a capacidade de sufrimento, que tan relevante foi no caso irlandés e que só de modo episódico se mostrou no campo do agrarismo galego, pero nunca no do nacionalismo. De feito, os conflitos sociais protagonizados polo agrarismo acabaron en diversas ocasións con mortes: cinco campesiños en Nebra (1916), tres en Guillarei (1922) e algún máis en diferentes localidades galegas (Sofán, Antas de Ulla, Chantada), conflitos que, en xeral, eran o resultado non tanto dunha "protesta primitiva» como dunha acción colectiva consciente. Estes sucesos non produciron «viúvas de heroes» como en Dublín ou Cork, pero foron feitos que estimularon a militancia agrarista e a súa confluencia co republicanismo nas eleccións municipais de 1931, que abriron a porta á Segunda República. Fronte ao recurso explícito á violencia, desde o Easter Rising ata a guerra con Inglaterra, os incentivos de que dispuxo o nacionalismo galego foron débiles, tanto para ampliar a militancia do movemento -claramente inferior á mobilización do agrarismo- como para identificar un sacrificio persoal coa «vitoria do ideal». Se «morrer por Irlanda», como se propuxeron os «heroes de Pascua», o alcalde de Cork e tantos outros, era unha aposta explícita por ese ideal, nada análogo se pode encontrar no movemento das Irmandades da Fala. Os poucos exemplos de violencia política daquela época están, en Galicia, no campo do agrarismo.

Como conclusión xeral, cómpre dicir que os sete anos das IF transcorridos entre 1916 e 1923 foron de grande intensidade histórica, dentro e fóra de Galicia. A experiencia das IF pasou por fases moi diversas: un rexionalismo aínda indeciso ata febreiro de 1918, cando fracasou na súa primeira experiencia electoral; unha definición claramente nacionalista a partir de novembro de 1918 e unha vontade de crear un partido político que, como dicía Risco, estaba «en 
germen» aínda en 1930, e unha hexemonía do nacionalismo cultural sobre o político, certamente desde o propio ano 1918, cando se incorpora o grupo ourensán, pero que se fixo máis patente a partir da escisión de 1922. O máis rechamante deste percurso das IF é que en poucos anos levaron a cabo un proceso de decantación máis ideolóxica que propiamente organizativa, sen que chegasen a un degrau de mobilización social comparable ao coetáneo movemento agrarista galego. Con este pano de fondo, os tres indicadores que escollemos como balance final mostran que as distancias entre o nacionalismo galego e os de Cataluña, o País Vasco e, desde logo, Irlanda son enormes, como revela o contraste que Otero Pedrayo lle apón ao "poeta e soñador» Adrián Soutelo, que na súa viaxe a Irlanda é animado a se converter nun auténtico «feniano», no canto de ser un avogado.

Pero tamén fica patente que o camiño andado polas IF foi cualitativamente decisivo: reaccionaron contra os seus devanceiros e foron conscientes de formar parte dunha xeración nova, a de 1916; apostaron por crear unha conciencia nacional que permitise asentar a «vitoria do ideal» no marco da diagnose pesimista de Risco de considerar o galego como un "pobo suicida», nunha carta privada de 1921 (Ventura 2010: 109). Pero tamén desprezaron o exercicio da política, por convicción ou por imposibilidade, o que fanou calquera opción de converter a causa do nacionalismo galego nun problema político dentro e fóra de Galicia. Seguir camiños paralelos aos do agrarismo galego foi, sen dúbida, a principal limitación desta fase das Irmandades da Fala. Se a acción de Pascua de 1916 foi cantada por William B. Yeats no seu poema «Easter, 1916» como unha ocasión na que aqueles «fenianos» patriotas e soñadores entregan a vida para lograren unha mudanza esencial: «todo cambiou, cambiou completamente: / unha terrible beleza naceu» («All changed, changed utterly: / A terrible beauty is born»), o principal poeta galego da altura, Ramón Cabanillas, despregou os seus mellores dotes poéticos para cantar o agrarismo, máis que o nacionalismo. Pero, mentres que no seu poema «iEn pé!» (1917) os irmáns galeguistas son invitados a actuar «arredor da bandeira azul e branca, / arredor da bandeira de 
Galicia», no seu poema dedicado aos «mártires de Sobredo» (Guillarei) ou no himno composto para a Acción Gallega de Basilio Álvarez (1915), a invocación á violencia é moito máis directa. Tamén na poesía galega o agrarismo vence ao nacionalismo.

¡Irmáns ¡ ¡Irmáns gallegos!

¡Dende Ortegal ó Miño

a folla do fouciño

fagamos rebrilar!

[...]

Antes de ser escravos,

¡irmáns, irmáns gallegos!

que corra a sangre a regos

dende a montana ó mar. 


\section{REFERENCIAS BIBLIOGRÁFICAS}

Agra Romero, María Xosé / Mariam Mariño Costales (2017): «A fraternidade nas Irmandades da Fala: 1916-1922», en Justo G. Beramendi / Uxío-Breogán Diéguez / Carme Fernández Pérez-Sanjulián / María Pilar García Negro / Xosé Manuel González Reboredo (eds.), Repensar Galicia: as Irmandades da Fala, Santiago de Compostela, Xunta de Galicia / Museo do Pobo Galego, 87-104.

Allegue Leira, Alberto (2017): «As Irmandades da Fala e a Liga Gaélica. Puntos en común e diverxencias de dúas iniciativas a prol da lingua minorizada", en Justo G. Beramendi / Uxío-Breogán Diéguez / Carme Fernández Pérez-Sanjulián / María Pilar García Negro / Xosé Manuel González Reboredo (eds.), Repensar Galicia: as Irmandades da Fala, Santiago de Compostela, Xunta de Galicia / Museo do Pobo Galego, 359-374.

BAEZA, Ricardo ([1930] 2010): La isla de los santos: itinerario en Irlanda, Tarragona, Igitur.

Beramendi, Justo G. (2007): De provincia a nación: historia do galeguismo politico, Vigo, Xerais.

Cabo Villaverde, Miguel (1998): O agrarismo, Vigo, A Nosa Terra.

Cabo Villaverde, Miguel (2006): «Solidaridad Gallega y el desafío al sistema de la Restauración, 1907-1911», Ayer, 64, 235-259.

Cabrera, María Dolores (2016): «Saúde e Patria! Cartas de Víctor Casas a Fermín Penzol», Grial, 54, núm. extra 212, 55-65.

CAmeIRÃo, Lurdes (2010): Epistolário espanhol de Teixeira de Pascoaes: (cartas de intelectuais espanhois a Teixeira de Pascoaes), Lisboa, Assírio \& Alvim.

Carmona, Xoán / Jordi Nadal (2005): El empeño industrial de Galicia: 250 años de historia, 1750-2000, A Coruña, Fundación Pedro Barrié de la Maza.

Carney, Sébastien (2015): Breiz Atao! Mordrel, Delaporte, Lainé, Fouéré : une mystique nationale (1901-1948), Rennes, Presses Universitaires de Rennes.

Domínguez CASTRO, Luis (2005): «Agrarismo y sociedad campesina en Galicia», en Jesús de Juana López I Julio Prada Rodríguez (coords.), Historia contemporánea de Galicia, Barcelona, Ariel.

Estévez Rodríguez, Xosé (1991): De la Triple Alianza al Pacto de San Sebastián (1923-1930): antecedentes del Galeuzca, San Sebastián, Universidad de Deusto.

FIGUEROA, Antón (1996): Lecturas alleas: sobre das relacións con outras literaturas, Santiago de Compostela, Sotelo Blanco.

FLORES DE LEMUS, Antonio (1926): «Sobre una dirección fundamental de la producción rural española», El Financiero, 405-414 [reedición en Hacienda Pública Española, 1976, 42-43].

Foster, Roy F. (2015): Vivid Faces: The Revolutionary Generation in Ireland, 1890-1923, London, Penguin Random House.

Gallástegui Unamuno, Cruz (1931): «Esbozo de programa agrario para Galicia. Conferencia pronunciada en Vigo el 3 de diciembre de 1930», Pontevedra, Imp. Celestino Peón [reedición en Revista Galega de Estudios Agrarios, 1979, 229-246].

Ínsua, Emilio Xosé (2005): Sobre O Mariscal, de Cabanillas e Villar Ponte, A Coruña, Universidade.

JimÉNEZ BLANCO, José Ignacio (1986): «Flores de Lemus y la producción rural de su tiempo», en José Luis García Delgado (ed.), La crisis de la Restauración: España, entre la primera guerra mundial y la II República, Madrid, Siglo XXI. 
Le Cloarec, Bernard (2016): «Breiz Atao e il rinnovamento del nazionalismo bretone nel primo dopoguerra", Nazioni e Regioni, 8, 51-66.

López Alonso-Cuevillas, Florentino (1920): «Dos nosos tempos», Nós, 1, 53-59.

MAdriñán, Xavier R. (2010): A nacionalización do pasado irlandés, 1845-1937, Santiago de Compostela, Centro Ramón Piñeiro para a Investigación en Humanidades.

MADRINÁÁn, Xavier R. (2017): «A revolución irlandesa en A Nosa Terra: unha crónica de ausencias, paixón e silencio», en Justo G. Beramendi / Uxío-Breogán Diéguez / Carme Fernández Pérez-Sanjulián / María Pilar García Negro / Xosé Manuel González Reboredo (eds.), Repensar Galicia: as Irmandades da Fala, Santiago de Compostela, Xunta de Galicia / Museo do Pobo Galego, 201-216.

MÁız, Ramón (1984): O rexionalismo galego: organización e ideoloxía (1886-1907), Sada, Ediciós do Castro.

Martínez López, Alberte (1995): Cooperativismo y transformaciones agrarias en Galicia, 1886-1943, Madrid, Ministerio de Agricultura, Pesca y Alimentación.

NúÑEZ SEIXAS, Xosé M. (1998): Emigrantes, caciques e indianos: o influxo sociopolítico da emigración transoceánica en Galicia (1900-1930), Vigo, Xerais.

NúNÉEZ SeIXAs, Xosé M. (2001): Entre Ginebra y Berlín: la cuestión de las minorías nacionales y la política internacional en Europa, 1914-1939, Madrid, Akal.

NúN̄EZ SEIXAS, Xosé M. (2010): Internacionalitzant el nacionalisme: el catalanisme politic i la qüestió de les minories nacionals a Europa (1914-1936), Catarroja (València), Afers.

O’Brien, Conor Cruise (1994): Ancestral Voices: Religion and Nationalism in Ireland, Dublin, Poolbeg [ed. española (1999): Voces ancestrales: religión y nacionalismo en Irlanda, Madrid, Espasa Calpe].

O'Brien, Conor Cruise (1999): Memoir: My life and Themes, London, Profile Books.

PASETA, Senia (1999): Before the Revolution: Nationalism, Social Change and Ireland's Catholic Elite, 1879-1922, Cork, Cork University Press.

RiQuer i Permanyer, Borja de (2001): Escolta, Espanya: la cuestión catalana en la época liberal, Madrid, Marcial Pons Historia.

RiQuer I PeRMAnYer, Borja de (2013): Alfonso XIII y Cambó: la monarquía y el nacionalismo politico, Barcelona, RBA.

Risco, Vicente ([1930] 1994): El problema político de Galicia, en Obras completas, vol. 4, Vigo, Galaxia.

Seixas Seonne, Miguel Anxo (2016): Luis Porteiro Garea e as Irmandades da Fala, Santiago de Compostela, Concello.

SERRANO SANZ, José María (1987): El viraje proteccionista de la Restauración: la politica comercial española, 1875-1895, Madrid, Siglo XXI.

ThIESSE, Anne-Marie (1999): La Création des identités nationales : Europe XVIII -XXe siècle, Paris, Seuil.

Torre Gómez, Hipólito de la (2002): El imperio del Rey: Alfonso XIII, Portugal y los ingleses (1907-1916), Mérida, Editora Regional de Extremadura.

UCELAY-DA CAL, Enric (1984): «"El Mirall de Catalunya”: models internacionals en el desenvolupament del nacionalisme i del separatisme català, 1875-1923", Estudios de Historia Social, 28-29, 213-219.

UCELAY-DA CAL, Enric (2006): «Entre el ejemplo italiano y el irlandés: la escisión generalizada de los nacionalismos hispanos, 1919-1922», Ayer, 63, 75-118.

VÁzQuez GonZÁlez, Alexandre (2015): Emigrantes galegos, transportes e remesas (1830-1930), A Coruña I Santiago de Compostela, Fundación Pedro Barrié de la Maza / Consello da Cultura Galega. 
Ventura Ruiz, Joaquim (ed.) (2010): Epistolario de Vicente Risco a Antón Losada Diéguez, Ourense, Deputación Provincial.

VILlaR PONTE, Antón (1916): Nacionalismo gallego: nuestra "afirmación» regional; apuntes para un libro, A Coruña, Tipografía Obrera.

Villar Ponte, Antón (1971): Pensamento e sementeira: leiciós de patriotismo galego, Buenos Aires, Ediciones Galicia.

Villar Ponte, Ramón / Ramón Cabanillas EnRíQuez (1977): A xeración do 16 (discurso e resposta lidos en 1951), A Coruña, Real Academia Galega.

VIllares PaZ, Ramón (1982): La propiedad de la tierra en Galicia, 1500-1936, Madrid, Siglo XXI.

Villares PaZ, Ramón (2005): «Restauración y dictadura en Galicia (1874-1930)», en Jesús de Juana López I Julio Prada Rodríguez (coords.), Historia contemporánea de Galicia, Barcelona, Ariel.

VILlares PaZ, Ramón (2017): Identidades e afectos patrios, Vigo, Galaxia.

VILlares PAZ, Ramón ([12007] 2018): Fuga e retorno de Adrián Solovio: sobre a educación sentimental dun intelectual galeguista, Vigo, Galaxia. 